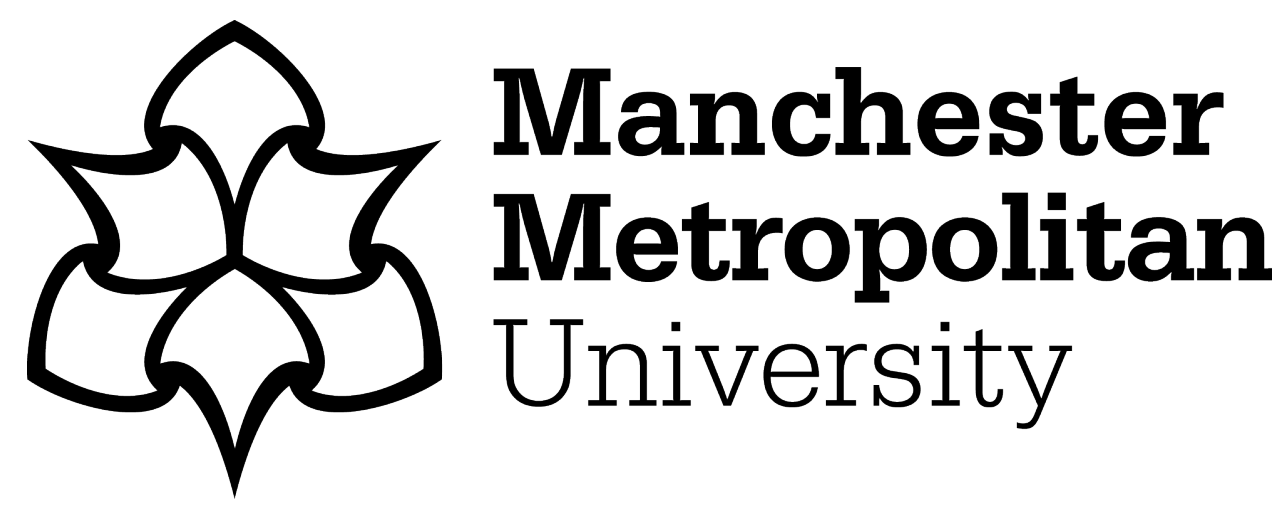

Thomas, Christopher (2020) Simone Weil: The Ethics of Affliction and the Aesthetics of Attention. International Journal of Philosophical Studies, 28 (2). pp. 145-167. ISSN 0967-2559

Downloaded from: https://e-space.mmu.ac.uk/625287/

Version: Accepted Version

Publisher: Informa UK Limited

DOI: https://doi.org/10.1080/09672559.2020.1736127

Please cite the published version 


\title{
Simone Weil: The Ethics of Affliction \\ and the Aesthetics of Attention
}

Author: Dr Christopher Thomas

Manchester Metropolitan University

Address:

Department of History, Politics and Philosophy

Manchester Metropolitan University

Geoffrey Manton Building

Manchester

M15 6LL

UK

Contact: c.thomas@mmu.ac.uk

$+44(0) 1612476138$

\begin{abstract}
:
For Simone Weil the invocation of 'rights' to address extreme human suffering-what she calls 'affliction'-is 'ludicrously inadequate'. Rights, Weil argues, invite a response, whereas what the afflicted require is not dialogue but simply to be heard. For Weil, hearing the 'cry' of the afflicted is the basis of all justice. The task of such a hearing is given over to Weil's concept of attention, which demands an ethics of creative silence. This paper will argue that central to Weil's ethics of attention, and thus the way she thinks we should show compassion and act justly, is the Kantian aesthetic concept of disinterestedness. I will argue that whilst Weil is influenced by Kant in multiple ways, it is his aesthetics, rather than his normative moral theory, that is most at play in her own ethical theory of attention.
\end{abstract}

Key Words: Simone Weil, attention, affliction, justice, Immanuel Kant, aesthetics. 


\title{
Simone Weil: The Ethics of Affliction \\ and the Aesthetics of Attention
}

\begin{abstract}
:
For Simone Weil the invocation of 'rights' to address extreme human suffering-what she calls 'affliction'-is 'ludicrously inadequate'. Rights, Weil argues, invite a response, whereas what the afflicted require is not dialogue but simply to be heard. For Weil, hearing the 'cry' of the afflicted is the basis of all justice. The task of such a hearing is given over to Weil's concept of attention, which demands an ethics of creative silence. This paper will argue that central to Weil's ethics of attention, and thus the way she thinks we should show compassion and act justly, is the Kantian aesthetic concept of disinterestedness. I will argue that whilst Weil is influenced by Kant in multiple ways, it is his aesthetics, rather than his normative moral theory, that is most at play in her own ethical theory of attention.
\end{abstract}

\section{Introduction}

In an essay on the relationship between Simone Weil and Emmanuel Levinas, Gillian Rose claims that what is foundational in each of their respective projects is to restore hearing to the centre of our concepts of justice (Rose 2017: 214-215). More specifically, Rose continues, the problem they both embrace is " $[. .$.$] how to present the cry of other human beings$ as higher than the claim of the autonomous individual." (Rose 2017:214). At the outset of her reading of both Levinas and Weil, Rose emphasises what is unique in each of their conceptions of justice: Over and above the positive claims of the autonomous individual for the administration of justice, what is instead required is a hearing of the other and, more specifically, a hearing of the cry of the one who suffers injustice. With this Rose picks up on one of the most startling moments in Weil's ethical and political philosophy, namely, her claim that what the afflicted require is not so much a positive allowance of freedom, but the silence of those who want to show compassion and deliver justice (HP 73). ${ }^{1}$ According to Weil, affording the afflicted the freedom to articulate their suffering is not particularly helpful if that

\footnotetext{
${ }^{1}$ All references to Weil's essay 'Human Personality' are from Weil 2005 and are abbreviated as HP followed by the page number of the above volume.
} 
voice is then rendered mute by the louder voices of those who speak in the "vocabulary of middle values' (HP 86). Given this, Weil's entire ethical philosophy revolves around this central problem: How to hear as a form of justness? The task of such a project is given over to one of Weil's most well-known concepts, attention. ${ }^{2}$ To attend to those who 'have had their tongue cut out' will give voice to the cry of affliction and allow for the first stages of justice to be delivered. Crucially, Weil's theory of how we begin to deliver justice is not grounded in the academic and legal structure of rights and the ability of an autonomous and rational mind to weigh up the claims of those who suffer. Rather, Weil's theory begins aesthetically, that is, with a discourse on how we begin to hear something. It is the argument of this article that what underpins Weil's theory of attention is an aesthetic schema derived in part from a key concept of Kant's aesthetic philosophy, namely, his theory of aesthetic disinterestedness.

Whilst Weil's implicit and explicit uses of Kant's philosophy have been remarked upon in the literature, the influence that Kant's aesthetic philosophy plays in her ethics of attention is something that has gone largely unremarked upon. In his extensive study of Weil's religious metaphysics, Miklos Vetö uncovers several of Weil's philosophical precursors and points to Kant as one of the most influential (Vetö 1994: 8). But such a project is not without its difficulties. Weil rarely cites the philosophical sources she is drawing upon, and when she does it is usually a classical reference to a Platonic dialogue or a Greek tragedy, rather than to a particular passage in the Critique of Pure Reason. To this extent, the parallels that Vetö draws between Weil's philosophy and, say, Kant's treatment of human autonomy or the structure of space and time, ${ }^{3}$ are subterranean; they are parallels that Vetö points to in order to suggest an implicit philosophical current that runs just under the surface of Weil's own philosophy. One of the tasks of reading Weil-the-philosopher is to identify this subterranean philosophy in order to further illuminate what Weil herself explicitly says. Continuing this method of reading Weil, this article will proceed across five sections. In sections one and two I outline Weil's critique of 'rights' and show that it derives from her distrust of the intellect's ability to confront the reality of affliction. In the face of the inability of discursive thought to confront injustice, Weil instead advocates a relation of 'silent attention' towards the afflicted. Following this claim, sections three and four develop a new reading of Weil's theory of attention grounded in the implicit use of Kant's concept of aesthetic 'disinterestedness'. Lastly, I further this connection

\footnotetext{
${ }^{2}$ For an excellent commentary on Weil's theory of attention see Cameron 2003. For commentaries that relate Weil's theory of attention to her general ontology and, specifically, to her concept of decreation, see Vetö 1994: 46, and Stone and Stone 2013: 102-112.

${ }^{3}$ See, respectively, Vetö 1994: 24 and n.19 of p167.
} 
by showing that Weil's theory of attention and Kant's aesthetic theory are motivated by an interest in exploring the capacity of humanity to confront 'life itself'.

The central argument of this article is that the current that runs through Weil's theory of attention is aesthetic and is drawn in part from Kant's aesthetic philosophy of the third Critique. By pointing to this Kantian thread, I hope to present the concept of attention in a new light, emphasising its aesthetic ground and arguing that it is Kant's aesthetic philosophy, rather than his normative ethical theory, that is most influential for Weil's own ethics of attention.

\section{'Rights' and the Mute Cry of Injustice}

At the beginning of her essay 'Human Personality' Weil sets out to critique the modern notion of 'rights' by outlining what the concept of rights misses when it is invoked in the service of addressing human suffering. ${ }^{4}$ Rights, Weil argues, refer only to the person, to the cry "[...] 'why has somebody else got more than I have'?" (HP 93). When we appeal to the use of rights to describe an injustice committed, we invoke only a comparative measure of justice whose basis is force. ${ }^{5}$ To quote Weil:

"The notion of rights is linked with the notion of sharing out, of exchange, of measured quantity. It has a commercial flavour, essentially evocative of legal claims and arguments. Rights are always asserted in a tone of contention; and when this tone is adopted, it must rely upon force in the background, or else it will be laughed at." (HP 81)

At its base, Weil's critique of rights is twofold. Firstly, rights are always articulated in a language that is foreign to true injustice and suffering. As Weil notes in another famous passage, the language of rights may be adequate for a farmer who needs to sell his eggs at a moderate price; he is able to say: 'I have the right to keep my eggs if I don't get a good enough price' (HP 83), but this commercial language is entirely inadequate for the young girl forced

\footnotetext{
${ }^{4}$ For Weil the modern notion of 'rights' is exemplified by the 1789 French revolution text Déclaration des droits de l'homme et du citoyen ('Declaration of the Rights of Man and of the Citizen').

${ }^{5}$ For Weil's detailed development of the concept of 'force' see her The Iliad or the Poem of Force. Indeed, at the very outset of this essay Weil echoes her critique of rights in virtue of their ground in force: "To define force-it is that $x$ that turns anybody who is subject to it into a thing." (Weil 2005: 183). Here Weil offers a definition of force as that which abstracts people from their humanity affording them only an economic status. To this end, if rights are always backed up by force then they function only to turn their subject into a commercial object, into a thing that is subject to exchange and argument and not a human being that demands to be heard.
} 
into prostitution, for "[...] in such a situation the word [rights] would sound ludicrously inadequate." (HP 83). Secondly, the language of rights always serves to set up dualisms, and thus the possibility of conflict between those who invoke their rights and the person(s) who are seen to infringe upon those rights. On Weil's account, rights "[...] evoke a latent war and awaken the spirit of contention" (HP 83), and thus do not allow for true compassion on either side. This latter point serves to further explain Weil's claim that the very idea of rights is grounded in the use of force and, as Rose points out, what Weil understands by force is an individualistic attempt to possess the world and its objects for oneself, an individualism that is foreign to the foundations of Weil's ethics (Rose 2017:217). For Weil, then, any appeal to the use of rights to defend and make visible human suffering only serves to debase and obscure the truth of suffering proper.

In contrast to the modern notion of rights Weil approvingly cites the Greeks whom, she claims, have no conception of rights and no words to express them. They, she continues, were content only with the name of justice (HP 82). The talk of rights differs from justice on the fundamental point of the cry. If we converse in the language of rights, and even worse in the language of 'personal rights', we miss what she calls the real problem. We hear only the false cry of 'why has somebody got more than I have?' over the real cry of injustice, the cry made inaudible by the claim and counter-claim of rights, namely, 'Why am I being hurt?' (HP 72). For Weil this latter cry is the measure of true justice for it expresses an attack on that which is sacred in every person: The inalienable expectation that good and not evil will be done to them (HP 71-2). When harm is done to a person the injustice committed is not at the level of the right of an individual to not be physically assaulted. Rather, the injustice occurs at the violence done to that basic assumption of all human life, that which is sacred and good in all human life, the expectation that one will receive good and not evil. As Weil explains, what stops her from putting out a man's eyes is not his right to live a life free from physical disability or his right to sight. Rather, what stops her is the knowledge that "[...] his soul would be lacerated by the thought that harm was being done to him." (HP 71). For Weil, the claim to rights misses the basic injustice of being the subject of harm; to concentrate on a person's rights misses what is truly at stake when one is blinded by the blows of another, namely, a violation of the good.

Weil's reasoning here relies upon two competing conceptions of justice, where one is only a shadow of the other. Firstly, there is justice as it pertains to the sacred, which has its source in the ultimate good, the expectation that one will receive good and not evil. And secondly there is justice as it pertains to the talk of rights, which is always comparative and characterised by the dualism of at least two persons each agitating their rights over the other. 
Weil argues that true injustice is done when what is sacred and good in human beings is violated, and there arises from the heart the cry, 'Why am I being hurt?'. In this instance the cry invoked moves beyond the individual person and their specific grievance, to an injustice committed towards what is common, sacred, and good across all human beings. This violation of the good is the properly basic injustice, and it is the same for all human beings regardless if they are a duke or a dustman, or if they have long arms or blue eyes (HP 71).

To make an appeal to rights is, for Weil, an inadequate way to frame and confront true injustice. When we agitate our rights in the face of violence and an apparent injustice, we appeal to a superficial level of justice that functions at the level of dialogue and force, rather than attention to the good and the compassion that follows such attentiveness. ${ }^{6}$ Rose neatly summarises this critique by claiming that Weil's aim is to "[...] substitute cry and response for the contention of the claim." (Rose 2017: 215). If the language of rights involves a cry of "why has someone got more than me?' and therefore invites a response in the form of an answer-if it invites dialogue-, then the cry 'why am I being hurt?' articulates a unilateral claim of injustice that demands not to be answered, but to be heard. ${ }^{7}$ According to Weil, such a cry is infallible and to this extent does not invite dialogue over its veracity (HP 93). Justice itself pertains to this cry, and to this extent the ground to Weil's entire ethical philosophy is the problem of how we can hear this cry, for as Weil tells us this is a mute cry, a cry from those who have had their tongue cut out by the overpowering discourse of rights (HP 91).

\section{Affliction and Thought}

\footnotetext{
${ }^{6}$ I will develop this point in the following sections.

${ }^{7}$ Weil is clear on this in an essay on the Pythagorean philosophy (Weil 1998). Here Weil maintains the impossibility of giving an adequate response to the cry of the afflicted. As Weil puts it, the principal effect of affliction is to force from the mouth the cry of 'why', just as Christ did on the cross. But for such a cry, articulated more fully as the question 'why am I being hurt?' (HP 72), there is no possibility of reply (Weil 1998: 198). If the cry of 'why' is taken as the search for a cause, then it will always be met with answers insufficient to its search, for according to Weil there is no finality to the universe and no adequate causal explanation that might be given. Thus, in place of an answer to the question of 'why', Weil states that the afflicted might instead come to hear a silence, a silence that has greater significance than any response to their affliction could ever have. In this silence one moves beyond the search for natural causes towards hearing something 'like God himself speaking' (Weil 1998: 199). Here, the cry of the afflicted and the silence of God create a harmony, and it is only in this harmony that the space for justice can be found (Weil 1998: 199). The importance of 'silence', developed briefly here as it relates to The Pythagorean Doctrine, is key to Weil's wider thinking about affliction and will be further developed below.
} 
But, who, exactly, are those whose cries of injustice go unheard? For Weil, these are the afflicted. Affliction (malheur) is a particular kind of human condition and at the outset of her essay 'The Love of God and Affliction' Weil distinguishes it from mere suffering, whilst nevertheless acknowledging that affliction is of 'the realm of suffering' (WG 76) ${ }^{8}$. Whilst Weil's language is sometimes loose on this point, occasionally using suffering and affliction interchangeably, she is nevertheless consistent in pointing out what she takes to be central for thinking about extreme suffering and affliction, namely, their particular relation to thought, or intelligence. Indeed, it is the relation of affliction to thought that imbues Weil's ethics with an aesthetic ground that, I will argue, is fundamentally Kantian.

According to Weil there is a disjunction between thought and affliction such that "Thought flies from affliction as promptly and irresistibly as an animal flies from death" (WG 77). Elsewhere Weil makes similar claims, stating "Thought revolts from contemplating affliction" (HP 85), and again that "Human thought is unable to acknowledge the reality of affliction." (HP 90). Most explicitly, Weil argues in the First and Last Notebooks that any thought of suffering or affliction cannot be of a discursive kind, and that ultimately thought is impotent to discover anything about either:

"The thought of suffering is not of a discursive kind. The mind comes slap up against physical suffering, affliction, like a fly against a pane of glass, without being able to make the slightest progress or discover anything new, and yet unable to prevent itself from returning to the attack." (FLN 483) ${ }^{9}$

For Weil, in the face of affliction the realm of thought appears as ineffective as the fly against a pane of glass. Thought comes up against affliction, but it is unable to acknowledge its reality or tell us anything about the lives of the afflicted. And yet what does this mean, and why does Weil think that thought turns away from the afflicted? Again, Weil's terminology is loose, at once claiming that thought, language, and the intellect are each an obstruction to the acknowledgement of the reality of affliction. But her point becomes more concrete when she drops the discussion of thought, and instead focusses on the relationship between truth and affliction, and the impotence of both the intellect and language in the face of each. To quote:

\footnotetext{
${ }^{8}$ All references from Weil's collection of essays Waiting on God are from Weil 1983 and are abbreviated as WG followed by the page number of the above volume.

${ }^{9}$ All references to Weil's First and Last Notebooks are from Weil 2015b and are abbreviated as FLN followed by the page number of the above volume.
} 
"There is a natural alliance between truth and affliction, because both of them are mute suppliants, eternally condemned to stand speechless in our presence.

Just as a vagrant accused of stealing a carrot from a field stands before a comfortably seated judge who keeps up an elegant flow of queries, comments and witticisms while the accused is unable to stammer a word, so truth stands before an intelligence which is concerned with the elegant manipulations of opinions." (HP 88)

For Weil it is the intellect and its expression in language that obscures our relationship to truth and affliction. As the judge chooses words, constructs sentences, and develops arguments in the name of rights and administering justice, so the accused is rendered mute. Likewise, for the ethical thinker who resides in the arguments and protestations of the intellect, so the subject of their thinking goes unheard and they miss the very thing they seek. Indeed, according to Weil, the very words that we choose to give voice to the afflicted actively damage those they are trying to help:

"To put into the mouth of the afflicted words from the vocabulary of middle values, such as democracy, rights, personality, is to offer them something which can bring them no good and will inevitably do them much harm." (HP 86) ${ }^{10}$

But why this hostility towards articulating affliction? ${ }^{11}$ Why are we unable to say anything about the afflicted without that very action negating the intention to alleviate suffering? For Weil, words are always chosen relative to the personality who speaks them. The

\footnotetext{
${ }^{10}$ See also HP 85

${ }^{11}$ And yet it should be noted that there are some compositions of words that are sufficient to articulate the cry of the afflicted. Of these Weil notes those "[...] heroes of real purity, the saints and geniuses, who can help the afflicted", of which she names "[...] the poet of the Iliad, Aeschylus, Sophocles, Shakespeare" (HP 88) and various others. Here Weil turns to the great poets and authors whose work reveals the impersonality essential to the beautiful and good, and thus to the recognition of the reality of the afflicted. And yet it is not the words so much as the beauty they radiate that allows affliction to be heard. As Weil puts it: "The radiance of beauty illumines affliction with the light of the spirit of justice and love, which is the only light by which human thought can confront affliction and report the truth of it." (HP 92). I don't have space to develop the relationship between beauty and affliction, but it is possible to say that for Weil beauty allows one to grasp something of affliction through the light that it casts. Through the beauty in Sophocles' plays we are silently directed towards the truth of affliction: "She, too, has no language; she does not speak; she says nothing. But she has a voice to cry out. She cries out and points to truth and justice who are dumb [...]" (HP 93) Once again, beauty does not articulate the truth of affliction so much as allow for a light through which it becomes visible to thought.
} 
judge who stands before the accused betrays his person and its attendant history in the words he chooses. He chooses the vocabulary of 'middle values' and recounts them 'through an elegant flow of witticisms' because these are the words through which he understands his own person and social milieu, a milieu that has never known the reality of affliction (HP 84-85). Insofar as the judge's words illumine only his person and its history, so the cry of the afflicted will be stifled and his words will 'inevitably do them much harm' (HP 86). Likewise, since truth and affliction are both 'mute suppliants' and have a 'natural alliance', the same reasoning applies to the acquisition of truth. Weil explains this with an example of arithmetic:

"Truth and beauty are impersonal. [...] If a child is doing a sum and does it wrong, the mistake bears the stamp of his personality. If he does the sum exactly right, his personality does not enter into it at all.” (HP 75)

Truth, just like the sum done correctly, will never bear the stamp of the person. If the judge seeks justice and the truth of affliction, then like the acquisition of truth his method must be one that avoids the mark of his person.

And yet in the face of the impossibility of thought to account for the reality of affliction, and in the face of language's impotence to articulate the injustice at the heart of affliction, Weil nevertheless retains the possibility of the 'miracle' of delivering justice and acknowledging the reality of affliction (WG 75/79, FLN 327). ${ }^{12}$ Indeed, according to Weil in 'The Love of God and Affliction', such a miracle can occur when one considers affliction at a distance (WG 82). Thus, the concept of 'distance' emerges at the crux of Weilian ethics and points to her theory of attention as that which allows for the cry of affliction to be heard, and for justice to be delivered.

\section{Attentive Distance}

Weil's theory of attention is worked out across her notebooks and collected essays and has received much ink in the literature. It is a multifaceted concept central to both her ethical philosophy and religious metaphysics. But it is in the two essays 'Reflections on the Right Use

\footnotetext{
${ }^{12}$ Whilst my presentation of Weil's treatment of language has portrayed her as sceptical towards language at best, and hostile towards it at worst, J. P. Little offers a small counter point, arguing that Weil took language with utmost seriousness despite its impotence in the face of truth and affliction. See Little 1996: 42
} 
of School Studies' and 'Human Personality' that the concept is most thoroughly developed in terms of its aesthetic ground. Following from the above discussion of affliction's relation to thought, I will now develop attention's relation to thought, before suggesting that Weil's theory of attention has its conceptual ground in an idea central to Kant's Critique of Judgment, namely, the necessary condition of disinterestedness for the aesthetic judgment of taste.

If, according to Weil, attention is that which allows the cry of affliction to be heard, then it is firstly an absence of all that which stymies the voice of the afflicted. Indeed, Weil herself says in 'Reflections on the Right use of School Studies' that "Attention is an effort, the greatest of all efforts perhaps, but it is a negative effort." (WG 71). Here, attention is understood negatively as a kind of suspension-an absence. More exactly, attention is conceived as a suspension of directed thought; a suspension of the discursive framework of thinking that we express through language, claim, and counter claim. Attention, then, takes the form of silence. In a passage that reveals the radicality of this, Weil claims that what the afflicted require is not so much a positive allowance of freedom, but the silence of the other to allow their cry to be heard. According to Weil what the afflicted require is "[...] a regime in which the public freedom of expression is characterised not so much by freedom as by an attentive silence in which this faint and inept cry can make itself heard." (HP 73). Over and above the freedom to express themselves-a freedom that is ultimately grounded in the language and structure of rights-, the afflicted require the attentive silence of the other, a kind of absence that allows for a non-discursive space through and by which their suffering might make itself heard. Typical to Weilian philosophy, the effort of attention emerges paradoxically as the activity of becoming-passive.

In opposition to the active enquiry of the intellect that seeks the causes of affliction and articulates them in words relative to the interests of the one who enquires, attention seeks to suspend this goal-orientated faculty. As Weil puts it: "Attention consists of suspending our thought, leaving it detached, empty and ready to be penetrated by the object." (WG 72). For Weil, attention is characterised by this double movement: It is at once the activity of directed attention towards the object or person one is attending to, but it is also a drawing away so as to let the truth of the object penetrate the one who attends. The practice of attention is, then, opposed to intellectual endeavour, for the reason that intellectual endeavour involves a seeking, whereas attention involves an absence of activity towards finality. As Weil puts it, in attention "[...] our thought should be empty, waiting, not seeking anything, but ready to receive in its naked truth the object which is to penetrate it." (WG 72 my emphasis). In order to hear the cry 
of the afflicted and confront its reality, the attentive person must be empty and waiting, which is to say, silent and open to the cry that marks the most basic injustice.

Whilst Weil's thoughts on the relation between attention and justice are worked out in most detail in both 'Human Personality' and 'Reflections on the Right Use of School Studies', these accounts appear to be problematized by what she notes of justice, and its expression, in the short essay 'Are We Struggling for Justice?' (Weil 1987). Here the importance of an attentive form of silence for delivering justice is replaced by another conceptual schema, what she calls the necessity of the 'madness of love' to attend to injustice. In this essay, as in 'Human Personality', Weil once again draws on the Greek conception of justice to develop her own theory, particularly relying on Thucydides definition of justice as 'mutual consent' (Weil 1987: 1). In turning to Thucydides, Weil aims to think through the power relations between people(s) that make justice and injustice possible. ${ }^{13}$ Following Thucydides, Weil argues that justice is only possible where there is equal necessity and consent on both sides. Such consent is premised on power, and where a power relation is unequal injustice will follow. Hence Weil is clear that where one has the power to force the consent of the other, then that person will not seek consent and injustice will take hold (Weil 1987: 2). This, she claims, is the point of view of the reasonable person: Reason dictates that where someone does not have the capacity to refuse, consent will not be sought (Weil 1987: 9-10).

If the prescriptions of reason demand that one does not seek consent where it is not necessary, then it is 'reasonable people' that sustain injustice (Weil 1987: 10). Here Weil points to the fact that reason does not allow for the possibility of justice, for reason does not allow that one might choose an uncertainty-consent being granted-over a certainty-consent being forced. In contrast to what reason demands, then, Weil argues that it is only the mad who are able to deliver justice, for it is only the mad who will seek consent where there is no power for it to be refused (Weil 1987: 3). But for Weil it is a particular kind of madness that aims at justice, a madness that whilst appearing in contrast to the justness of the passivity of attention, is actually bound up with the central tenet of attention, namely, a compassionate emptying of the self(Weil 1987: 9). As Weil makes clear:

\footnotetext{
${ }^{13}$ See also 'The Pythagorean Doctrine' (Weil 1998: 174), wherein Weil once again uses Thucydides definition of justice to bring together the notions of consent, justice, and thinking in the first person.
} 
"The spirit of justice is nothing other than the supreme and perfect flower of the madness of love.

The madness of love turns compassion into a far more powerful motive for any kind of action, including fighting, than splendour, glory or even honour.

It compels one to abandon everything for compassion and, as St. Paul says of Christ, to empty oneself." (Weil 1987: 9)

Here the madness of love is theorised alongside compassion, such that through the madness of love compassion becomes the strongest motive for action, a motive much stronger than what reason otherwise demands of us. And yet despite this talk of action, Weil nevertheless stays true to her paradoxical presentation of what compassionate action consists in. Again, as with her presentation of the attentive act as a form of silent suspension in both 'Human Personality' and the essays in Waiting on God, action is understood here in the sense of a diminution of the self through abandonment. For Weil, the madness of love is a true form of madness because it ignores what reason prescribes and instead occasions an abandonment of the power of the rational and autonomous self. When the madness of love dwells within us we consent to being less than what we might be at the level of force, and instead open ourselves up to the being of the other through a realisation of their free capacity for refusal.

Whilst Weil's language and conceptual schema in 'Are We Struggling for Justice?' differs from that of 'Human Personality' and Waiting on God, they nevertheless share two central points: Firstly, all three argue for the rejection of the rational, or intellectual, for the delivery of justice; and secondly each aims to highlight the importance of the abandonment of the power of the self for the delivery of justice. The madness of love as the occasion for justice is, then, a second but not inconsistent way that Weil aims to think through the nature of justice. In 'Human Personality' and the essays collected in Waiting on God, Weil argues that we must practice attentive silence to hear the cry of injustice, whilst in 'Are We Struggling for Justice?' this same silence is expressed as a form of mad love in view of a hearing of the power of refusal, and thus the very being of the other. But whichever way Weil forms the problem and its solution, hearing emerges as central to her thinking about justice.

But as well as 'hearing', the theme of 'silence' is also fundamental to Weil's thinking about justice, and in a section in Letter to a Priest Weil develops the activity of becomingsilent as a practice of attention, and further outlines its relation to thinking and the intelligence. In this letter Weil explains that the intelligence can only come into contact with the reality of 
affliction "[...] after having passed through silence through the midst of the unintelligible." (LP 37). ${ }^{14}$ In attentive silence, the intelligence finds an energy to turn its focus towards the afflicted, whose condition is now illuminated by this silence. ${ }^{15}$ But there is a further passage in these letters wherein Weil appeals to analogy to explain the idea of becoming-passive through silently attending to the afflicted, a passage that reveals the aesthetic ground to her concept of attention. To quote:

"In the same way, when one gives one's whole attention to a wholly beautiful piece of music (and the same applies to architecture, painting, etc.), the intelligence finds therein nothing to affirm or deny. But all the soul's faculties, including the intelligence, become silent and are wrapped up in listening. The listening itself is applied to an incomprehensible object, but one which contains a part of reality and of good. And the intelligence, which cannot seize hold of any truth therein, finds therein nevertheless a food.” (LP 38)

In the same way that our intelligence must retreat in order for us to become silent and attend to the afflicted, so in the perception of a beautiful work of art our thinking retreats and we become entirely enveloped in the beautiful. Here Weil turns to a theory of aesthetic experience in order to explain the ethical stance one must take towards the afflicted. In aesthetic experience the intellect is denied its role in the affirmation or denial of its object, and instead the experience of the beautiful is theorised along the lines of listening as a form of silent attention. For one to really listen to a piece of music, for one to attend silently and become aware of the mute voice of the afflicted, the soul's goal-directed faculties, including that of the intelligence, must retreat into the background. Just as with the experience of the beautiful, so in the acceptance of the reality of affliction the activity of the self must become diminished through a practice of silent attention.

At this point the aesthetic ground to Weil's theory of attention becomes apparent. More specifically, this aesthetic ground is Kantian and reveals her use of the aesthetic concept of

\footnotetext{
${ }^{14}$ All references to Weil's Letter to a Priest are from Weil 2002a and are abbreviated as LP followed by the page number of the above volume

${ }^{15}$ In a different text, but relating to the same point, Weil approvingly cites an 'Eskimo story', which suggests the relation of the light of attention to the object one seeks: “"In the eternal darkness, the crow, unable to find any food, longed for light, and the earth was illumined."' (WG 68). Such an analogy seems to suggest that affliction can never be confronted through an active search, but only through the light of passive attention will the reality of affliction make itself known.
} 
'disinterest'. ${ }^{16}$ Indeed, Weil turns to this Kantian aesthetic concept at several places in 'Human Personality' when developing her theory of attention. For instance, when developing the claim that truth and affliction can only be accepted through attention, which is a form of love, Weil describes attention as disinterested: "The name of this intense, pure, disinterested, gratuitous attention is love." (HP 92). Further on, Weil re-iterates the relationship between attention and love, once again describing attention as 'pure and disinterested' (HP 92). At this point, one might object that Weil's terminology and use of the notion of disinterest is coincidental, and ultimately unrelated to Kant's aesthetic theory. But we know that Weil studied Kant's Critique of Judgment, or at the very least was aware of the arguments of Kant's third Critique, for she gave lectures on them. For instance, in the Lectures on Philosophy we find a lecture on aesthetic experience in general, but which is expounded in relation to the driving arguments of the third Critique. In this lecture there are notes on, for instance, the universal communicability of the pleasure that arises from a judgment of the beautiful, the harmony of imagination and intellect in a judgment of the beautiful, the non-conceptual state of the judgment of taste (and therefore the absence of 'finality' in a judgment of the beautiful), and the condition of disinterestedness in a judgment of taste (LoP 185-7). ${ }^{17}$ In these lectures Weil's thinking about aesthetics take on a particularly Kantian flavour, thereby demonstrating her familiarly with the third Critique.

But beyond her knowledge of Kantian aesthetics, and beyond the various references to attention being 'disinterested', what is it about the Kantian notion of disinterest that is visible in her theorisation of attention, and how does this influence relate to the ethical relation one must take towards the afflicted?

\section{The Aesthetic Condition of Attention}

It has been noted in the literature that Weil's philosophy has three dominant influences: Plato, Descartes, and Kant (Vetö 1994: 2-3). And yet whilst her philosophy exhibits various Kantian traits, Miklos Vetö has argued that her aesthetics is ultimately non-Kantian (Vetö 1994: 93). ${ }^{18}$ My argument does not turn on whether Weil's thoughts on beauty are or are not

\footnotetext{
${ }^{16}$ While the notion of 'disinterest' as an aesthetic concept is not an invention of Kant's (on the history of the concept see Stolnitz 1961), it is Kant's aesthetics that made it widely known, and it is certainly Kant's aesthetics that Weil was most familiar with.

${ }^{17}$ All references to Weil's 'Lectures on Philosophy' are from Weil 1978 and are abbreviated as LoP followed by the page number of the above volume

${ }^{18}$ This is not to say, however, that Weil's thinking on art and beauty does not exhibit some influence of Kantian aesthetics. Miklos Vetö also shows, for instance, that the proximity of beauty to the good reveals Kantian elements, claiming that '[...] there is no other key notion in Weil's thought that better
} 
Kantian in any sense, but rather the more modest claim that her theorisation of attention exhibits certain key elements of Kantian aesthetic theory. More specifically, it is the idea of disinterest in an aesthetic judgment of the beautiful in Kant that, I believe, is also at work in Weil's theory of attention. In what follows I will develop how this central concept of Kant's aesthetic theory plays a role in Weil's theorisation of attention, and further how this relates to her treatment of affliction. But to do this I want to first give a brief account of how the theory of 'disinterestedness' is put to work in Kant's Critique of Judgment.

In Kant's aesthetic theory, a judgment of the beautiful must exhibit a relation of disinterestedness towards its object (CJ $§ 2,205) .{ }^{19}$ Likewise, a judgment of beauty must be universal, which is to say, when one makes the claim 'the rose is beautiful' one makes it for everyone as a universal judgment that demands assent (CJ $\S 6,210)$. These two conditions of disinterestedness and universality are related and together fulfil the specific conditions of a pure judgment of the beautiful. To this extent, aesthetic judgments of taste are of a very particular kind, and Kant outlines various other kinds of judgment that resemble the aesthetic judgment of taste, but which ultimately fall short of it. In the opening sections of the Analytic of the Beautiful Kant states that judgments of both the good and the agreeable are often confused with pure aesthetic judgments of taste. According to Kant, whilst judgments of the good and agreeable are similar to judgments of the beautiful, neither contain the requirement of universality and disinterestedness that the judgment of the beautiful demands. Indeed, for Kant, both the agreeable and the good contain an 'interest' relative to the subject who judges, and as a consequence of this they cannot demand the assent of anyone other than the judging subject. As Kant puts it:

"Both the agreeable and the good refer to our power of desire and hence carry a liking with them, the agreeable a liking that is conditioned pathologically by stimuli (stimuli), the good a pure practical liking that is determined not just by the presentation of the object but also by the presentation of the subject's connection with the existence of the object; i.e., what we like is not just the object but its existence as well. A judgment of taste, on the other hand, is merely contemplative, i.e., it is a judgment that is indifferent to the

reveals a dual Platonic and Kantian heredity than her notion of the beautiful.' (Vetö 1994: 90). To the extent that Weil's theory of beauty is bound up with the good, her aesthetics can also be seen as Kantian. ${ }^{19}$ All references to the Critique of Judgment are from Kant 1987 and abbreviated as CJ. Section numbers are followed by page numbers of the Akademie edition of Kant's works as used by Pluhar in Kant 1987. 
existence of the object: it [considers] the character of the object only by holding it up to our feeling of pleasure or displeasure." (CJ $§ 5,209)$

Here, Kant is clear as to where a true aesthetic judgment of taste differs from judgments of the agreeable and the good. As he puts it, both the agreeable and the good carry a liking with them, and this liking refers back to the subject's specific relation to the existence of the object in question. To take the agreeable, this involves a liking insofar as the senses like something about the object in sensation. More explicitly, Kant will say that judgments of the agreeable always involve an 'interest', for the subjective liking of the agreeable refers back to the desires qua interests of the one who judges (CJ $\S 3,205-8)$. To the extent that the agreeable refers to the interests of the one who judges, it cannot be a universal judgment.

The good, on the other hand, carries a different kind of interest, a different kind of liking. Whereas the agreeable carries an interest based on subjective sensation, the good cannot be an aesthetic judgment of taste because it entails a cognitive judgment of what kind of thing the object of judgment is meant to be. The judgment of the good betrays an interest in its object insofar as its object is brought under the principles of reason, using the concept of purpose (CJ $\S 4,207-10)$. In different words, to judge something good, we must make a comparative judgment of it in relation to its purpose, and to this extent we reveal a cognitive interest in the existence of the object which is specific to our person. Once again, insofar as the judgment of the good involves a conceptual interest specific to the one who judges, it cannot demand universal assent.

Contrary to judgments of the good and the agreeable, an aesthetic judgment of taste remains neutral regarding the existence of its object. An aesthetic judgment of taste reveals no interest in the object on the part of the subject, and hence is always a 'disinterested' judgment that is 'free' from the sensory or conceptual interests that would prevent the judgment being truly universal. Whilst the agreeable, the good, and the aesthetic judgment of taste all reveal either an interest or liking relative to the judging subject, only the aesthetic judgment of taste involves a liking in something other than the object of judgment, namely, the pleasure that arrives from the judgment itself. This, of course, is Kant's claim that the liking we feel in the judgment of beauty derives from the 'feeling of life' (CJ $\S 1,203-5)$ that is a consequence of the free play of the imagination and intellect (CJ $\$ 9,217-18)$. This feeling of pleasure is what distinguishes the true aesthetic judgment of taste from all other forms of judgment (be they aesthetic or cognitive). For Kant, then, the aesthetic judgment of taste pleases of itself, with no subjective interests brought to bear on the judgment. 
Like the aesthetic judgement of taste in Kant, Weil's account of ethical attention must also avoid all reference to subjective interest. Human thought is unable to acknowledge the reality of affliction precisely because of the inability of discursive thinking to approach its subject without bringing the interests of the thinker to bear on the one who is thought (HP 89). To think of suffering erects a barrier that, no matter how nuanced one's thought is, cannot be breached. As Weil puts it in an analogy, the realm of intelligence is a kind of 'cell' that one is imprisoned within, and it matters little, she says, whether this cell is 'narrow or wide' (HP 89/90). In the realm of the intellect, the mind is filled with self-referring relations of words that, with each utterance, fortify the walls of one's intellectual prison. One's intellect can extend far and wide, but ultimately it is limited in its capacity to articulate that which exists on a different register to it. Attention, however, is the antidote to the force of language. In contrast to the language of the intellect that smothers the voice of the other, attention suspends this goalorientated activity, instead demonstrating a passive disinterest that allows the reality of affliction into one's thought. As Weil puts it: "Attention consists of suspending our thought, leaving it detached, empty and ready to be penetrated by the object." (WG 72). In opposition to the walls of the cell, attention allows one to become-porous, to break through the barriers of discursive thought and allow the reality of the other in. This is a form of disinterested engagement that effaces the interests of the one who stops and turns towards the afflicted. If the intellect and its expression in language betray an interest, and to this extent fail to enact the passivity required for the cry to be heard, then the capacity of silent, disinterested attention involves a reduction of the person in view of an openness to the truth of the other. Such a relation is non-discursive and aesthetic. It is a relation in which Weil's active and productive ethics occurs by way of an active-passivity, a becoming-silent, a form of disinterested attention expressed in the diminution of the subject and the hearing of the other. ${ }^{20}$

Insofar as interests negate both attention and aesthetic judgments of the beautiful, so Weil's ethics hints at an aesthetic ground. But as well as this there is another key point in both Kantian aesthetic theory and Weilian attention that further suggests their closeness. For Weil, the attentive relation involves a relation to the non-existence of the other. As Weil notes in her

\footnotetext{
${ }^{20}$ As Alessia Ricciardi neatly puts it regarding this form of active-passivity, Weil "[...] redefines action in terms of liberation from one's own subjectivity, thus exalting a state of passivity [...]" (Ricciardi 2009: 78).
} 
essay 'Forms of the Implicit Love of God', "Creative attention means really giving our attention to what does not exist." (WG 105). She goes on to explain that affliction has robbed the afflicted of their humanity, and in this sense the afflicted cease to exist as humans. But regardless of this, the Samaritan "[...] gives his attention all the same to this humanity which is absent" (WG 105). Here attention is exercised in abstraction from the existence of the thing one attends to. The Samaritan exhibits 'real attention' because his actions are not directed towards the existence of a human being and to the social obligations of rights and middle values that oblige one to show compassion to those who suffer. Rather, his attention is pure because it is without object and without end. ${ }^{21}$

Likewise, in an aesthetic judgment of taste the same disinterestedness in the existence of the object of judgment is a pre-condition for its universality. As Kant says "A judgment of taste $[. .$.$] is merely contemplative, i.e., it is a judgment that is indifferent to the existence of$ the object" (CJ $\S 5,209-10)$. In the aesthetic judgment of taste, one does not refer to the existence of the object in the judgment, for this would involve either a cognitive relation of the good, or a sensible relation of the agreeable, both of which do not allow for the universality required for a judgment of the beautiful. Indeed, these kinds of judgments are conditioned " $[\ldots]$ by the presentation of the subject's connection with the existence of the object; i.e., what we like is not just the object but its existence as well." (CJ §5, 209-10 emphasis added). In contrast to this, the judgment of the beautiful must be made without regard to the existence of its object. Like the pure attention of the Samaritan that does not refer to the existence of the afflicted, so the aesthetic judgment of taste does not refer to the existence of its object to ground its judgment. Indeed, this posture is furthered by what Weil notes of 'detachment' in her unfinished essay 'Some Reflections on the Concept of Value: On Valéry's claim that

\footnotetext{
${ }^{21}$ And yet it is worth pointing out that for Weil, to attend to the non-existence of a thing does not imply a negation of reality, and thus a negation of the reality of suffering (I thank an anonymous reviewer for raising this). Attention is a form of love (WG 75), and according to Weil: "Nothing which exists is absolutely worthy of love. We must therefore love that which does not exist. But this object of love which does not exist is not devoid of reality, is not a fiction." (NB 220) To attend to the non-existence of a thing is, then, not to deny its reality, but it is to look past the particularities of existence and towards the wider real it partakes in. Further, whilst this claim is directly aimed at the non-existence of God, it nevertheless also applies to the good as it is expressed through the cry of the afflicted. When we attend to the cry of the afflicted we do not hear a personal plea connected to the specifics of existence, but rather a cry that marks a violation of the impersonal good, that which is sacred and identical in all human beings. For Weil, then, attention is not expressed at the level of the existence of the person-that which is immediately graspable (NB 220)-, but rather at the level of the reality of the good that their cry expresses. See also McCullough 2014 (specifically pp.62-66) for an excellent discussion of Weil's demand of loving that which does not exist.
} 
philosophy is poetry' (Weil 2015a). Here, Weil develops the practice of detachment along similar lines to her theory of attentive disinterest, claiming that "Detachment is a renunciation of all possible ends without exception, a renunciation that puts a void in the place of the future just as the immanent approach of death does." (Weil 2015a: 32). Detachment, for Weil, involves a practice of thought that is immanent only to itself. Like attentive disinterest, detachment does not exhibit the teleological character of discursive thought and aims at nothing other than the perpetuation of itself. Weil develops this paradox of the pure reflective aspect of detachment through her philosophy of value. All thought is implicated in value, she contends, for all thought demands an effort, and all effort is directed towards a certain value we take to be the end of that effort (Weil 2015a: 31). But the effort of detachment, like attentive disinterest, is not orientated towards an object or thought, for it is itself the supreme value. In opposition to the telos implicated in all un-detached thought, detached thought is empty and open (WG 72); it puts a void in place of an end and in so doing opens up a space that invites the affliction of the other in. For Weil, detachment, like attentive disinterest, is as much a renunciation of ends as it is the creator of an empty space, or silence, that allows the cry of affliction to be articulated. By not aiming at a value beyond itself, detachment appears as the supreme value for it is without direction and without an end. Just like the Samaritan who does not express an interest in the one he turns to, and who thus does not exhibit an end to his action that would refer only to his own power of thinking, so detached thought is without finality, without personal interest, and thus radically open to the presence of the other.

Key to understanding the logic of both detachment and disinterestedness is the relation of the will to attention in Weil, and to the aesthetic judgment of taste in Kant, for it is an absence of direction from the will that marks each relation out. In the last sentence of the fourth section of the Analytic of the Beautiful, Kant draws an equivalence between interest and the willing of something. Here he says: "But to will something and to have a liking for its existence, i.e., to take an interest in it, are identical." (CJ §4, 209-10). The context to this equivalence is found a little further on in the same section where Kant addresses the highest good, namely, the moral good and the sphere of ethics more broadly. Kant's claim is that the moral good involves the highest form of interest "For the good is the object of the will (a power of desire that is determined by reason).” (CJ $\S 4,209-10)$. For Kant, acting morally in view of the absolute good necessarily involves an act of the will on behalf of the prescriptions of reason. When we act morally we do so out of our rational duty to abide by the moral law, but we must also will to 
follow the moral law. ${ }^{22}$ To this extent, all actions that have any moral worth involve an interest and, specifically, an interest in, or will for, the good. Moral admiration is afforded, then, not simply to people who act on behalf of reason and follow the moral law, but who at the same time freely impose this law upon themselves by showing an interest in acting in view of the good.

An interest, or will, in the moral actions of an agent in Kant's ethical theory is a prerequisite. ${ }^{23}$ But in contrast to the moral judgment, the pure aesthetic judgment of taste negates all willing, and thus all interests in the existence of the object of judgment. Here, then, we can discern a unique move in Weilian ethics. In opposition to Kantian moral theory that prescribes a will and thus an interest in the object of its moral action, Weil instead makes use of Kant's aesthetic theory for her own ethics, making the aesthetic condition of disinterest key to her ethics of attention. In opposition to the judge who wills and aims at the good through the language of rights, the Samaritan undertakes an aesthetic practice of attention devoid of all willed action and interest. Weil is clear regarding the diminution of the will in the truly attentive act, linking together the limits of both the will and the intelligence in the First and Last Notebooks, claiming that: "The good begins at a point beyond the reach of the will, as truth begins at a point beyond the reach of intelligence." (FLN 262) and again in the Notebooks: "Attention is intimately related to desire-not to the will, but to desire." ${ }^{24}$ (NB 527). ${ }^{25}$ Indeed, and as Robert Reed has commented, Weilian attention functions

"[...] not by applying the will to the intentional act of somehow creating the other but by removing the will and substituting pure consent. For it is precisely the will that covers over reality with imaginary creations conceived to keep its world familiar and safe." (Reed 2017: 115)

\footnotetext{
${ }^{22}$ See the opening sections of the first chapter of the Groundwork for the necessity of the will for the good. See Kant 1964: 61-2.

${ }^{23}$ Kant, however, is clear that the categorical imperative itself is determined without any interests. See Kant 1964: 71-74.

${ }^{24}$ Here Weil's reference to desire points to her concept of 'desire without an object' (Weil 2002: 22), which in turn raises another connection to Kantian philosophy, namely, the condition of purposiveness without a purpose in an aesthetic judgment of the beautiful (see CJ \$10-11 219-222). I do not have space to develop the connection between these two concepts, but the former certainly echoes the latter and furthers the reading of Weil's ethics as having a Kantian aesthetic ground.

${ }^{25}$ All references to Weil's Notebooks are from Weil 1956 and are abbreviated as NB followed by the page number of the above volume.
} 
For Weil, the good, which is the aim of all ethics, stands forever removed from the action of the will, and thus from the realm of Kantian ethics. ${ }^{26}$ Instead of turning to Kant's moral theory for the development of her own ethics, Weil appears to turn to the third Critique, and specifically the aesthetics of the beautiful. The condition of disinterestedness becomes key to hearing the cry of an injustice committed against the ultimate good. One cannot will oneself to hear this cry, but one can allow it to be articulated through the aesthetic practice of silent, disinterested attention. ${ }^{27}$

\section{Attention, Affliction, and the Feeling of Life}

According to Kant, in the pleasure that attends an aesthetic judgment the subject is confronted with a 'feeling of life':

"Here the presentation is referred only to the subject, namely, to his feeling of life [Lebensgefühl], under the name of pleasure or displeasure, and this forms the basis of a very special power of discriminating and judging." (CJ §1, 204-5, emphasis added)

This passage is often overlooked in studies of the third Critique, with commentators instead concentrating on its more memorable concepts. ${ }^{28}$ And yet Kant's reference to a 'feeling of life' at the very beginning of the Analytic of the Beautiful illuminates a central condition of his aesthetic theory, namely, the universal communicability of all aesthetic judgments. Indeed,

\footnotetext{
${ }^{26}$ For an opposing reading of the relation of the good to will see Vetö 1994: 52. Here Vetö claims that there is a 'Kantian moment' in Weil's thinking about the good evident in her claim that: "my will for the good. Pure and inexhaustible good is in that very will only" (NB 491, quoted in Vetö 1994: 52). Such a claim appears to stand in direct contradiction to her other claims presented above. And yet in relation to her wider religious metaphysics it is the latter claim that holds true. Indeed, if attention is a practice of decreation, which Vetö himself holds (see Vetö 1994: 46), then the will is that which needs to be abandoned in order to return to God that which he renounced in creation, namely, his absolute freedom. Taken in this wider metaphysical context, the will and the good stand removed from one another, with the latter beginning, for Weil, 'at a point beyond the reach of the will'.

${ }^{27}$ It might be objected that the practice of attention is not so much an aesthetic relation as it is a religious one. Indeed, Weil herself identifies the love of God as the substance of attention (WG 75). Furthermore, Weil seems to suggest in the same essay that attention, whilst potentially developed through a range of activities, is ultimately in the service of refining prayer (WG 66). And most explicitly in the Notebooks Weil writes that "Extreme attention is what constitutes the creative faculty in man, and the only form of extreme attention is a religious one." (NB 441). These passages seem to suggest a religious ground to attention. And yet whilst attention may be directed towards religious ends, it is not so essentially (WG 67). Rather, attention is a faculty of the mind (WG 66) and it precedes its expression in the various practices of prayer, geometry, or listening that it might be directed towards.

${ }^{28}$ On this see, Porter 2017 specifically footnote 8 .
} 
proper attention to the concept of the 'feeling of life' in the third Critique will lead, as one commentator has put it, to "[...] an aesthetics that takes as its object life itself." (Porter 2017: 7). For Kant, when we make an aesthetic judgment, and this may or may not include an aesthetic judgment of the beautiful, the presentation of the object is referred to a feeling in the subject. This feeling that arises in an aesthetic judgment is what Kant calls a 'feeling of life', which in turn is named as a feeling of pleasure or displeasure. As we have seen above, such a judgment is not cognitive but aesthetic, since the judgment refers only to the subject and their feeling. But what is this 'feeling of life' that marks out an aesthetic judgment of taste? According to Béatrice Longuenesse, Kant's 'feeling of life' does not merely relate to our biological life, and thus is not limited to the particular feelings of each biological being. Rather, the 'feeling of life' is closer to "[...] what Hegel will later call "spirit": the life of the universal community of human minds." (Longuenesse 2006: 199). Acknowledging the various potential problems with her use of Hegel's notion of spirit to develop the notion of the 'feeling of life', Longuenesse nevertheless continues to elucidate the analogy by emphasising the importance of the 'feeling of life' for the subjective universality that is requisite for an aesthetic judgment of taste. Whilst granting that all pleasure or displeasure is the feeling of a living entity in a biological sense-an attraction or emotion relative to a particular set of desires-, Longuenesse continues that if all pleasures or displeasures were purely biological there would not be any possibility of the judgment becoming universal. To this end Longuenesse argues that the 'feeling of pleasure' of an aesthetic judgment, considered under the name of pleasure or displeasure, must have a ground other than the biological and, specifically, an a priori ground. Indeed, according to Longuenesse, the 'feeling of life' in Kant is a feeling of the life "[...] of an a priori grounded community of judging subjects" (Longuenesse 2006: 200). The feeling of a pleasure or displeasure in a judgment of taste is, then, a feeling of connection to a community of 'judging subjects', to a broader human community that share in 'life' as such. What an aesthetic judgment of taste does, then, is connect one to this wider human community by giving rise to a 'feeling of life', without this feeling being connected to any singular life. In short, the aesthetic judgment of taste lets the judging subject feel life itself.

Just as with the aesthetic judgment of taste in Kant, attention allows one to confront the reality of affliction, and thus brings one face to face with life at its most bare. Indeed, this latter point is precisely why thought fails to acknowledge affliction:

"Human thought is unable to acknowledge the reality of affliction. To acknowledge the reality of affliction means saying to oneself: 'I may lose at any moment, through the 
play of circumstances over which I have no control, anything whatsoever that I possess, including those things which are so intimately mine that I consider them as being myself. There is nothing that I might not lose. It could happen at any moment that what I am might be abolished and replaced by anything whatsoever of the filthiest and most contemptible sort."” (HP 90)

Here, thought is said to flee from affliction because the latter confronts one with the frailty of life itself: Affliction brings us face to face with what we have by showing us what we have to lose. As Stuart Jesson has commented, we do not turn away from the afflicted because of a lack of moral sensitivity-it is not a failing of the will-, but rather because "[...] of a deepseated fear and unwillingness to encounter the real." (Jesson 2017: 123). Undoubtedly Weil has a very specific understanding of the real, but the unwillingness to turn our gaze to the afflicted is likewise the impossibility of thought to face the reality of life at its most bare.

In contrast to the poverty of thought to face unadorned life, the faculty of attention allows for a realisation of the reality of affliction by confronting the attentive subject with the possibility of their own affliction, that is to say, with bare life. As Weil writes above, acknowledging the reality of affliction means saying to oneself: 'there is nothing that I might not lose', and this is equally to put oneself in the position of the afflicted-other such that their reality becomes shared and they cease to be 'other'. Attending to the afflicted means becoming aware of a life that we all participate in. In the aesthetics of attention, the confrontation with life precedes, and is prioritised over, cognitive and conceptual relations that present the subject only with an image or shadow of life. The judge can never confront the reality of affliction because his words betray his person, always curling back onto himself and his particular form of life. But when one truly attends, one engages disinterestedly such that the cry of the afflicted can be heard over the demands of the autonomous individual. As Rose maintains, and as this article opened with, Weil's ethics takes as its starting point the problem of "[...] how to present the cry of other human beings as higher than the claim of the autonomous individual." (Rose 2017: 214). One way that Weil anticipates such a relation occurring is by employing the aesthetics of disinterestedness in her ethics. In disinterested attention the cry of the other, which is an expression of a violation of what is common to all human beings, is heard over the claim of the individual life of the one who listens. Like the 'feeling of life' that one is confronted with in an aesthetic judgment of taste, so attentive disinterest functions to reduce the claim of the individual who attends, instead allowing for life as such to reveal itself. 


\section{Bibliography}

Cameron, S (2003) 'The Practice of Attention: Simone Weil's Performance of Impersonality', in Critical Inquiry, Vol 29, No. 2, pp. 216-252

Jesson, S (2017) 'Compassion, Consolation, and the Sharing of Attention', in Simone Weil and Continental Philosophy ed. Rebecca Rozelle-Stone, London \& New York, Rowman and Littlefield

Kant, I (1964) The Moral Law: Kant's Groundwork of the Metaphysics of Morals, trans. H.J Patton, London, Hutchinson University Library

Kant, I (1987) Critique of Judgment, trans. Werner S. Pluhar, Indianapolis/Cambridge, Hackett Publishing Company

Little, J P (1996) 'Simone Weil and the Limits of Language', in The Beauty that Saves: Essays on aesthetics and language in Simone Weil ed. John Dunaway and Eric O. Springstead, Georgia, Mercer University Press

Longuenesse, B (2006) 'Kant's Leading Thread in the Analytic of the Beautiful', in ed. Rebecca Kukla, Aesthetics and Cognition in Kant's Critical Philosophy, Cambridge, Cambridge University Press

McCullough, L (2014) The Religious Philosophy of Simone Weil: An Introduction, London, I.B. Tauris

Porter, J (2017) 'Beauty, Value, and the Aesthetics of Life in Kant and Aristotle' in Beauty and Form, ed. T. Pfau and V. Soni, Repubics of Letters, Vol 5 no.1, (January)

Reed, R (2017) 'Levinas and Weil: Ethics after Auschwitz', in Simone Weil and Continental Philosophy ed. Rebecca Rozelle-Stone, London \& New York, Rowman and Littlefield

Rose, G (2017) 'Angry Angels - Simone Weil and Emmanuel Levinas', in Judaism and Modernity: Philosophical Essays, London and New York, Verso

Roselle-Stone, R and Stone, L (2013), Simone Weil and Theology, London, Bloomsbury

Ricciardi, A (2009) 'From Decreation to Bare Life: Weil, Agamben, and the Impolitical', in diacritics, vol. 39.2, pp. 75-93

Stolnitz, J (1961) 'On the Origins of "Aesthetic Disinterestedness"', in The Journal of Aesthetics and Art Criticism, Vol. 20, No. 2, pp. 131-143

Vetö, M (1994) The Religious Metaphysics of Simone Weil, trans. Joan Dargan, New York, State University of New York Press 
Weil, S (1956) The Notebooks of Simone Weil, trans. Arthur Wills, 2 vols., Edinburgh, T \& A Constable Ltd.

Weil, S (1978) Lectures on Philosophy, trans. Hugh Price, Cambridge, Cambridge University Press

Weil, S (1983) Waiting on God, trans. Emma Craufurd, Glasgow, Collins Fount Paperbacks

Weil, S (1987) 'Are We Struggling for Justice?' trans. Barabas, M in Philosophical Investigations 10:1 January 1987, pp.1-10

Weil, S (1998) Intimations of Christianity Among the Ancient Greeks, Oxon, Routledge

Weil, S (2002) Gravity and Grace, trans. Emma Crawford and Mario von der Ruhr, London and New York, Routledge

Weil, S (2002a) Letter to a Priest, London and New York, Routledge

Weil, S (2005) Simone Weil: An Anthology, ed. Siân Miles, New York, Penguin

Weil, S (2015a) Simone Weil: Late Philosophical Writings, ed. Springstead, E, trans. Springstead E and Schmidt L, Indiana, University of Notre Dame Press

Weil, S (2015b) First and Last Notebooks, trans. Richard Rees, Eugene, Wipf and Stock Publishers 